\title{
Original
}

\section{Effect of Magnesium, Strontium or Fluoride Ions on in vitro Activities of Odontoblast-like Cells (MDPC-23)}

\author{
Miho Inoue ${ }^{1)}$, Racquel Z.LeGeros²), Masahisa Inoue ${ }^{3)}$, Ramin Rohanizadeh²), Liang Guo ${ }^{4)}$, Robert Davidson ${ }^{4)}$, \\ Kan Rui ${ }^{1)}$, Hitoshi Nagatsuka ${ }^{1)}$ and Noriyuki Nagai ${ }^{1)}$ \\ ${ }^{1)}$ Department of Oral Pathology and Medicine, Okayama University Graduate School of Medicine, Dentistry and Pharmaceutical \\ Sciences, Okayama, Japan. \\ ${ }^{2)}$ Department of Biomaterials \& Biomimetics, New York University College of Dentistry, New York, USA. \\ ${ }^{3)}$ Laboratories for Structure and Function Research, Faculty of Pharmaceutical Sciences, Tokushima Bunri University, Tokushima , Japan. \\ ${ }^{4)}$ Department of Periodontology, New York University College of Dentistry, New York, USA. \\ (Accepted for publication, April 15, 2005)
}

\begin{abstract}
Magnesium (Mg), strontium (Sr) or fluoride (F) ions have been shown to affect in vitro activities of bone cells and in vivo mineralization. The purpose of this study was to investigate the effect of $\mathrm{Mg}, \mathrm{Sr}$ and $\mathrm{F}$ ions on the activities of odontoblast-like cells (MDPC-23) using an in vitro cell culture model. Mg, Sr or F ions were added to the medium in the following concentrations: $\mathrm{Mg}-1,5,10 \mathrm{mM}$; $\mathrm{Sr}-0.05,0.1,0.3,1 \mathrm{mM}$; F0.005, 0.01, 0.05, $0.1 \mathrm{mM}$. Results were observed after 1, 7 and 14 days using Von Kossa staining, scanning and transmission electron microscopy. Preliminary results showed the following: Mg ions demonstrated a positive effect at low concentrations and a negative effect at high concentrations; Sr ions demonstrated a positive dose dependent effect up to a concentration of $0.1 \mathrm{mM}$ and a negative effect at higher concentrations; and $\mathrm{F}$ ions demonstrated a positive dose-dependent effect up to a concentration of $0.005 \mathrm{mM}$ and inhibitory effects at higher concentrations. This preliminary study showed that the positive or negative effects of $\mathrm{Mg}, \mathrm{Sr}$ or F ions on odontoblastic activities (proliferation and mineralization) depend on their concentration levels in the environment.
\end{abstract}

Key words: Magnesium, Strontium, Fluoride, odontoblast

\section{Introduction}

Magnesium (Mg), strontium (Sr) or fluoride (F) ions were shown to have an effect on in vitro activities of bone cells (osteoblasts and osteoclasts) and were reported to act on several levels to alter the complex cascade of events that regulate the mineralization process ${ }^{1-4}$. These elements have also been involved in therapeutic agents in the management of osteoporosis ${ }^{5-7)}$.

$\mathrm{Mg}$ has been associated with the mineralization of calcified tissues, mainly in bones and teeth ${ }^{4}$. Mg indirectly influences mineral metabolism, for example through activation of alkaline phosphatase. Mg directly influences, or even controls, the crystallization processes of mineral substances as well as the pattern of mineral formation ${ }^{8-11)}$.

Sr has long been known to cause rickets when fed to growing animals at a sufficiently high dose. Dietary $\mathrm{Sr}$ induces rickets in either calcium-replete ${ }^{12,13)}$ or calcium-deficient animals ${ }^{(14)}$. Sr acts on several levels to alter the complex cascade of events that

Corresponding Author: Miho Inoue, PhD.Department of Oral Pathology and Medicine, Okayama University Graduate School of Medicine, Dentistry and PharmaceuticalScience2-5-1 Shikatacho Okayama City 700-8525 Okayama Japa.Phone: +81-86-235-6652 Fax: +81-86-235-6654 E-mail: mi8@ccr.tokushima -u.ac.jp regulate the mineralization process. In addition to displacement of $\mathrm{Ca}^{2+}$ from an existing matrix-bound mineral phase, binding of $\mathrm{Sr}^{2+}$ to a calcifiable collagenous matrix can also occur by its interaction with a site normally involved in the binding of $\mathrm{Ca}^{2+}$ during the initial step of calcification ${ }^{15)}$. Sr also affects the organic matrix composition locally ${ }^{16)}$ which implies an altered elaboration of matrix components by cells ${ }^{12,17)}$. Sr was shown to affect bone formation in vivo and resorption in vivo and in vitro ${ }^{7)}$. In vivo studies showed that Sr salts stimulate parameters of bone formation in rodents and humans, and this result in increased trabecular bone volume. At low dosage levels, stable Sr was reported to improve the vertebral bone density in osteoporotic patients ${ }^{18}$.

$\mathrm{F}$ is an important therapeutic agent in the treatment of osteoporosis, but has toxic effects at higher doses or with chronic exposure ${ }^{19)}$. F influences bone growth both on a biological level, by acting as a mitogenic agent. The in vivo toxic effects of $\mathrm{F}$ are: hypomineralization of newly formed osteoid, hypermineralization of bone and, in endemic fluorosis, formation of woven bone $\mathrm{e}^{20)}$. Lower doses of F, on the other hand, can be used to increase bone mass in a regular fashion without any noticeable formation of mineralization defects ${ }^{19,21)}$. The effects of $F$ on bone cells in 
Miho Inoue et.al.: Effect of Mg, Sr, F ions in vitro activities of MDPC23

monolayer culture are well known: fluoride has a dose-dependent effect on cell proliferation, extracellular matrix production, and alkaline phosphate activity ${ }^{1,3)}$. F-treated bones were reported to have an affect on cell activities of osteoblast-like cells ${ }^{22)}$ in vitro while F-substituted carbonatehydroxyapatite were shown to promote bone formation in vivo ${ }^{23)}$. F-treated dentin and F-substituted apatite were shown to inhibit osteoclast resorption ${ }^{24,25)}$.

While many studies have reported on the effect of $\mathrm{Mg}$, Sr or F ions on bone cells (osteoblast-like and osteoclast-like), the effect of these ions on odontoblast-like cells have not been investigated to date. The purpose of this preliminary study was to investigate the effects of high and low levels of $\mathrm{Mg}$, Sr, or F ion concentrations on in vitro activities (proliferation and differentiation) of odontoblast-like cells.

\section{Materials \& Methods}

\section{Cell cultures}

MDPC-23 cloned 3T6 cells of 18-day CD-1 fetal mouse molar dental papillae (odontoblast-like ${ }^{26)}$ was inoculated at a density of 5000 cells $/ \mathrm{cm}^{2}$, and cultured in alpha modified medium (Cellgro Mediatech, Inc., Herndon, VA, USA), containing $10 \%$ fetal bovine serum (FBS), ascorbic acid (50 mg/mL) and bglycerophosphate (2 mM). $\mathrm{MgCl}_{2}, \mathrm{SrCl}_{2}$, and $\mathrm{NaF}$ reagents (Fisher Scientific, Springfield, NJ, USA) were used as the source of $\mathrm{Mg}$, Sr or F ions, respectively. Mg, Sr, or F ions were added to the medium in the following concentrations: $\mathrm{Mg}-1,5,10 \mathrm{mM}$; Sr - 0.05, 0.1, 0.3, $1 \mathrm{mM}$; F - 0.005, 0.01, 0.05, 0.1 mM. The media (control) included $\mathrm{MgSO}_{4}(0.8 \mathrm{mM})$ and $\mathrm{CaCl}_{2}(1.8 \mathrm{mM})$. The cells were passaged and incubated for a day prior to placement in medium, then changed treated medium, and sampled at 7 days (confluent of mono-layer) and 14 days (mineralization). The cells were maintained in a $5 \% \mathrm{CO}_{2}$ atmosphere.

\section{Von Kossa Staining}

Each sample was washed three times with phosphate buffer saline (PBS), fixed with $10 \%$ formaldehyde for $30 \mathrm{~min}$ at room temperature, and then washed three more times with PBS. Five percent aqueous silver nitrate was added to samples in the dark room for $30 \mathrm{~min}$, and then washed three times with distilled water. The samples were exposed to UV light for $30 \mathrm{~min}$ and observed by light microscopy. The staining area was calculated using imaging analyzer (BIOQUANT NOVA, R\&M Biometrics, Inc., Nashville, TN, USA).

\section{Cell count}

The cells were treated with trypsin, diluted with PBS, and counted using the Coulter counter (COULTER Z2 - Particle count \& Size Analyzer).

\section{Scanning electron microscopy (SEM) analysis}

The specimens were fixed using solution consisting of $2 \%$ glutaraldehyde in $0.1 \mathrm{M}$ Na- cacodylate- $\mathrm{HCl}$ buffer with $0.1 \mathrm{M}$ sucrose (pH 7.2) and dehydrated in $70 \%, 80 \%, 90 \%$, and $100 \%$ ethanol for 30 min each. The plates were observed by SEM (JEOL/ JSM-5400).

\section{Transmission electron microscopy (TEM) analysis}

The specimens were fixed in a mixture of $2 \%$ glutaraldehyde in $0.1 \mathrm{M}$ Na- cacodylate-HCl buffer with $0.1 \mathrm{M}$ sucrose (pH 7.2), and post-fixed with $1 \%$ osmium tetroxide. After that, eponembedded ultrathin sections were prepared, double-stained, and examined under H800 transmission electron microscope (Hitachi Co., Japan).

\section{Statistical analysis}

The Von Kossa staining data was compared to the control group and each group, and was subjected to non-parametric analysis. Statistical differences among group were determined using the Kruskal-Wallis test and the Mann-Whitney U-test. A P-value of 0.05 was considered to be statistically significant. All data were presented as means \pm standard error.

\section{Results \\ Cell culture and cell count \\ Odontoblast-like cells (MDPC-23) in Mg- and Sr-containing media displayed no remarkable difference compared with those in control in any period of proliferation. In media containing 5 $\mathrm{mM}$ and $10 \mathrm{mM} \mathrm{Mg}$ or Sr, cells became detached after reaching confluence. Cell proliferation was initially inhibited but slowly increased in F-containing media in a dose-dependent manner. Most of the cells in F-containing media were dead after 2 weeks, but did not detach.}

\section{Von Kossa staining}

After 7 days (Fig. 2A), with cells in the control group, Von Kossa staining revealed formation of mineralized nodules. The intensity of staining (indicating nodule formation) was similar for both control and cells in media containing with $1 \mathrm{mM} \mathrm{Mg}$, but much less with cells in media containing $5 \mathrm{mM}$ and $10 \mathrm{mM} \mathrm{Mg}$. Less nodule formation was observed with cells in media containing $0.05 \mathrm{mM}$ and $0.1 \mathrm{mM}$ Sr compared to the control group (0.05 $\mathrm{mM}<0.1 \mathrm{mM}$ ); no nodule or less formation was observed with cells in media containing $0.3 \mathrm{mM}$ and $1 \mathrm{mM}$ Sr $(0.3 \mathrm{mM}>1 \mathrm{mM}$ ). Compared to the control group, cells in media containing 0.005 $\mathrm{mM} F$ formed less number of nodules while cells in media containing $0.1 \mathrm{mM}$ F formed more nodules. Nodule formation was not observed with cells in media containing $0.01 \mathrm{mM}$ and $0.05 \mathrm{mM}$ F.

After 14 days (Fig.1, Fig.2B), cells in the control group and 1 $\mathrm{mmol} / \mathrm{L} \mathrm{Mg-containing} \mathrm{media} \mathrm{displayed} \mathrm{increased} \mathrm{mineralization}$ and started to detach. Mineralized nodules were not observed and 


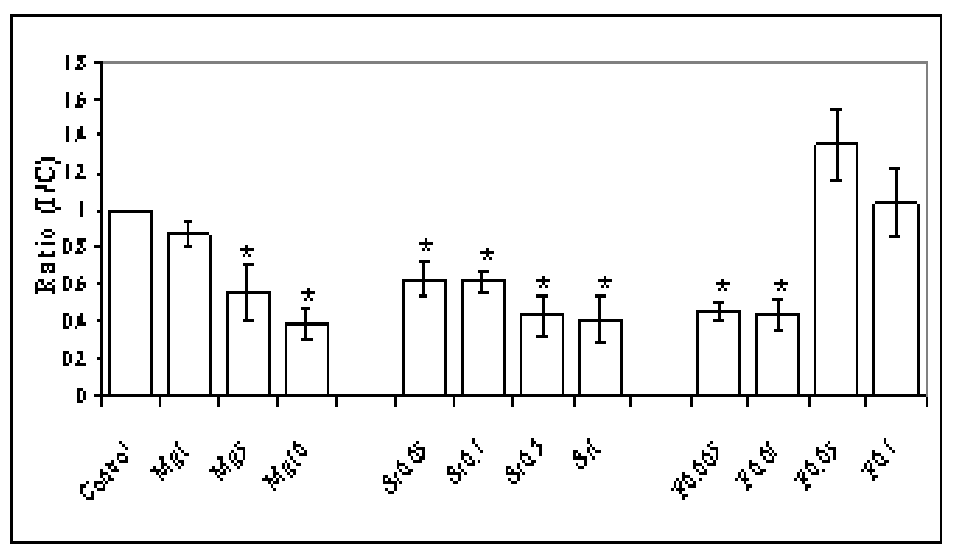

Fig.1 Ratio (I/C) of mineralized area in media with (I) and without (C) ions using Von Kossa staining after 14 days. Significant differences among groups using Kruskal-Wallis test: $\mathrm{P}<0.05$. Each bar represents means \pm standard error. Comparison between the control group and each group were made separately using the Mann-Witney nonparametric U-tests. ${ }^{*} \mathrm{P}<0.05$

cells were detached in media containing $5 \mathrm{mM}$ and $10 \mathrm{mM} \mathrm{Mg}$. Cells in media containing $0.05 \mathrm{mM}$ and $0.1 \mathrm{mM}$ Sr also displayed increased number of nodules $(0.05 \mathrm{mM}<0.1 \mathrm{mM})$, but less than the control group, and cells in media containing $0.3 \mathrm{mM}$ and 1 $\mathrm{mM}$ Sr formed less number of nodules. Cells in media containing $0.05 \mathrm{mM}$ and $0.1 \mathrm{mM} F$ formed less nodules than those in the control group, while cells in media containing $0.05 \mathrm{mM}$ and 0.1
mM F formed more nodules or deposited on the bottom of the wells.

\section{Morphological features of SEM}

The morphological features of the cells in control and in media containing $\mathrm{Mg}$, Sr, or F ions are shown in Fig.3. MDPC-23 (odontoblast-like) cells after 1 day: cells in Mg- and F-treated
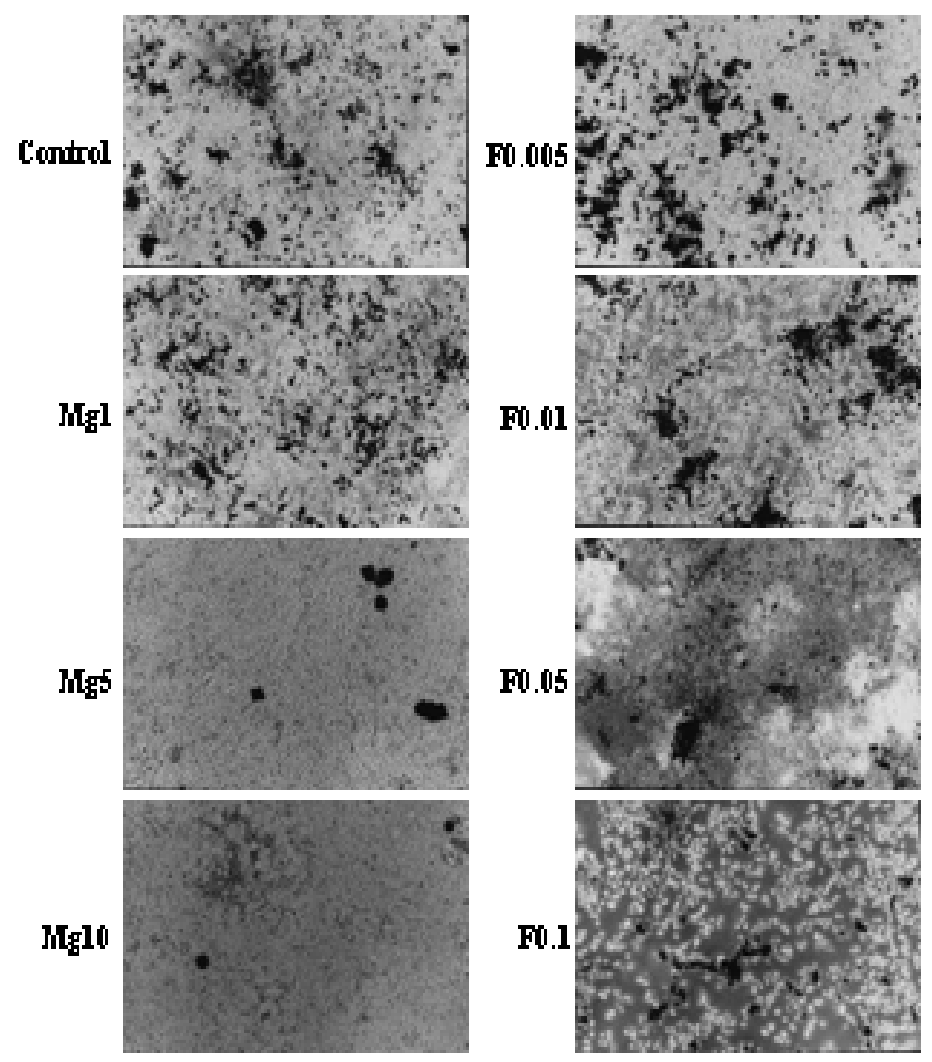

Fig.2 Results after Von Kossa Staining: After 14 days, black staining indicates mineralization. 

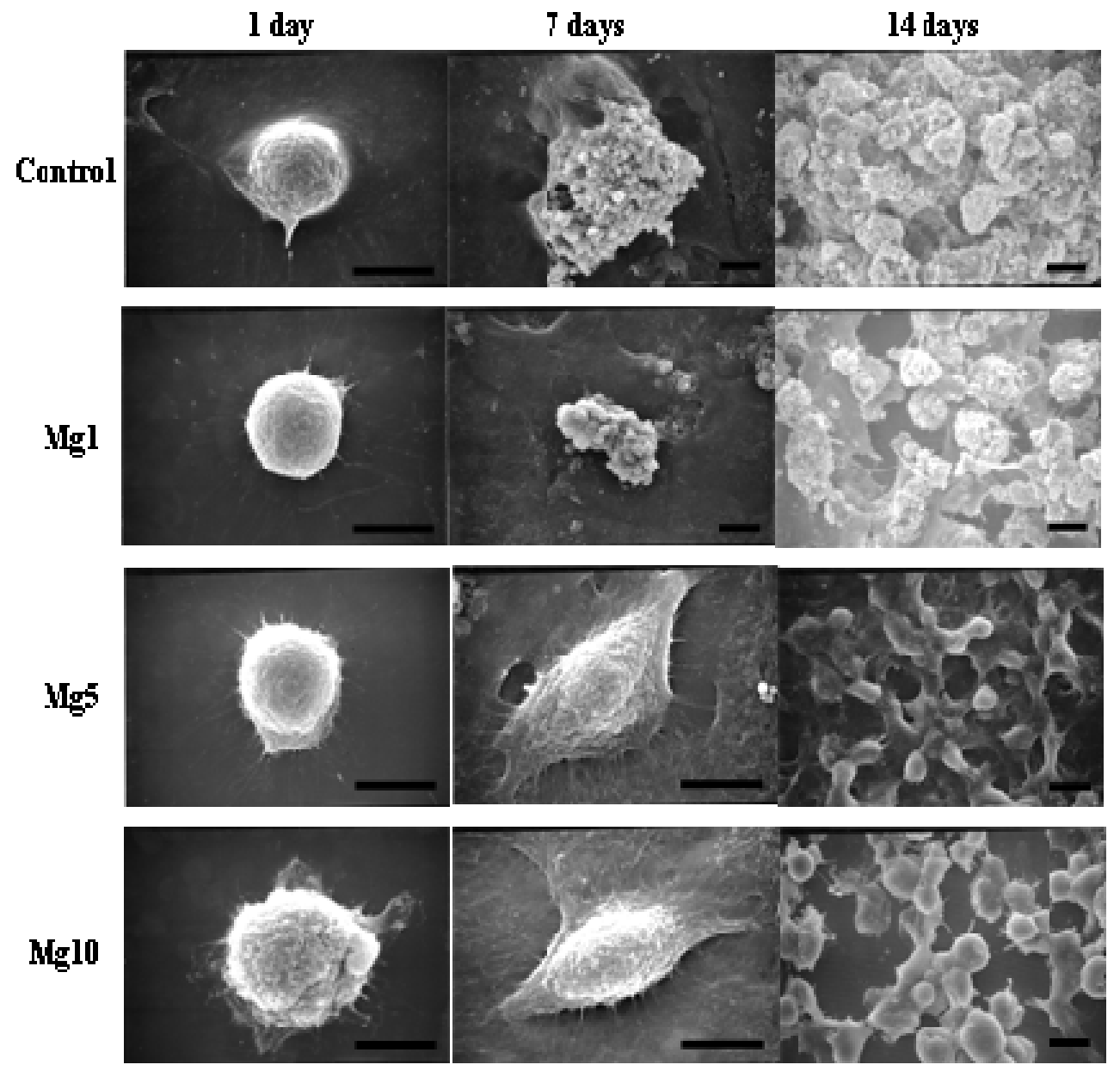

Fig.3(A). Scanning electron microscopy (SEM) micrographs showing the morphology of odontoblastlike cells (MDPC-23) in culture media containing: (A) Mg ions (1, 5, $10 \mathrm{mM}$ ) compared to control,

media displayed more filopodia than the control group. The abundance of filopodia was inversely related to the $\mathrm{F}$ concentration: the higher the concentration, the less number of filopodia observed.

MDPC-23 cells in Mg-containing media after 7 days (Fig. 3A) cells in media with $1 \mathrm{mM}$ Mg formed smaller sized mineralized nodules as compared to the control group. Cells in media containing $5 \mathrm{mM}$ and $10 \mathrm{mM}$ Mg changed their shapes from round to oval and did not form mineralized granules on cell surface.

MDPC-23 cells in Mg-containing media after 14 days (Fig. 3A)

cells in media with $1 \mathrm{mM}$ Mg formed numerous nodules, but the abundance of mineralized granules was less than those of the control group. Cells in media containing $5 \mathrm{mM}$ and $10 \mathrm{mM} \mathrm{Mg}$ remained without any mineralized granules, and these cell surfaces became smoother, and the lamellipodia decreased as the $\mathrm{Mg}$ concentration increased.
MDPC-23 cells in Sr-containing media after 7 days (Fig. 3B): cells also formed smaller sized mineralized nodules compared to those in the control. The surface of cells in media treated with 1 $\mathrm{mM} \mathrm{Sr}$ appeared smoother compared to those in the control and to those in media treated with $0.1 \mathrm{mM}$ and $0.3 \mathrm{mM} \mathrm{Sr}$.

MDPC-23 cells in Sr-containing media after 14 days (Fig. 3B)

the number of mineralized granules on the cell surfaces decreased as the Srion concentration in media increased.

MDPC-23 cells in F-containing media after 7 days (Fig. 3C) cells were arranged in clusters. Mineralized granules were not observed. In media with $0.1 \mathrm{mM} F$, mineralized granules were observed on lamellipodia and on the plate surfaces.

\section{MDPC-23 cells in F-containing media after 14 days (Fig. 3C)} the number of mineralized granules on surfaces of cells in Fcontaining media was less than those in control and decreased 

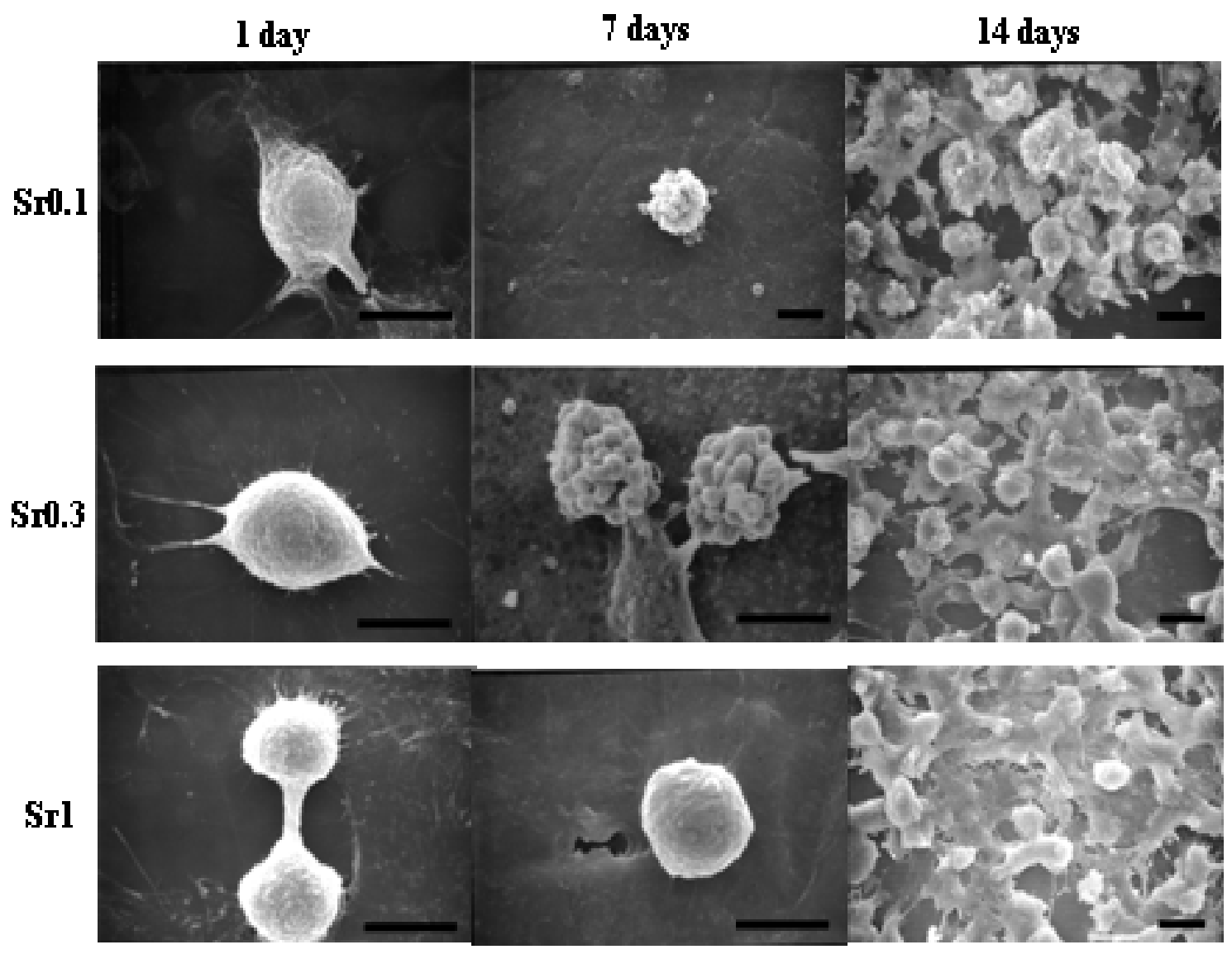

Fig.3 (B). Scanning electron microscopy (SEM) micrographs showing the morphology of odontoblast-like cells (MDPC-23) in culture media containing: (B) Sr ions (0.1, 0.3 and $1 \mathrm{mM}$ ) compared to control.

with increasing F ion concentration. Mineralized granules were also observed on the plate surfaces.

\section{Morphological features of TEM}

In the control group (Fig.4A,B) after 14 days, MDPC23 cells have the feature of extending a cellular process and polarity. There are lots of collagen fibers and nodules around the cell.

In $1 \mathrm{mM} \mathrm{Mg}$ (Fig.4C), the cells showed a tendency to loose their cell polarities. The cell shape showed irregular process. Vacuolations of the rough endoplasmic reticulum were seen in the cytoplasm. On the other hand, collagen fibers and nodules were decreased.

In 10mM Mg (Fig.4D), many vacuoles were observed in the process as well as in the cytoplasm. The cellular membranes were disintegrated. No collagen fibers and nodules were produced.

In 1mM Sr (Fig.4E), lots of microvilli can be observed. The rough endoplasmic reticulum have little vacuole. No collagen fibers were produced.

In $0.1 \mathrm{mM} F$ (Fig.4F), the cell organelles disappeared. The cells have various size of intracytoplasmic vacuoles. The cells produced microvilli.

\section{Discussion}

This preliminary study showed that high Mg concentration in the cell culture in media had a toxic effect on the odontoblastic cells and thus prevented the formation of extracellular matrix. This result is consistent with a similar effect of Mg on bone cells (27). Furthermore, although Mg did not affect the proliferation of MDPC-23 cells directly, a dose dependent effect on the mineralization was indicated by Von Kossa staining and SEM. In media containing $5 \mathrm{mM}$ and $10 \mathrm{mM} \mathrm{Mg}$, MDPC-23 cells tended to detach easily and lamellipodia were decreased. It seemed that Mg affected the cell structure and decreased their abilities to adhere. According to the observation on TEM, the nodules were less dose-dependent. This result was consistent with the results of Von Kossa staining and SEM. Interestingly, the observation on SEM was not so different between control and $1 \mathrm{mM} \mathrm{Mg}$, otherwise the observation of $1 \mathrm{mM} \mathrm{Mg}$ showed deformity compared to control. This result was based on the assumption that cell deformity started from intracellular to extracellular.

Results of this study suggest that Sr ions do not affect the proliferation and the structure of MDPC-23 cells. However $\mathrm{Sr}$ 

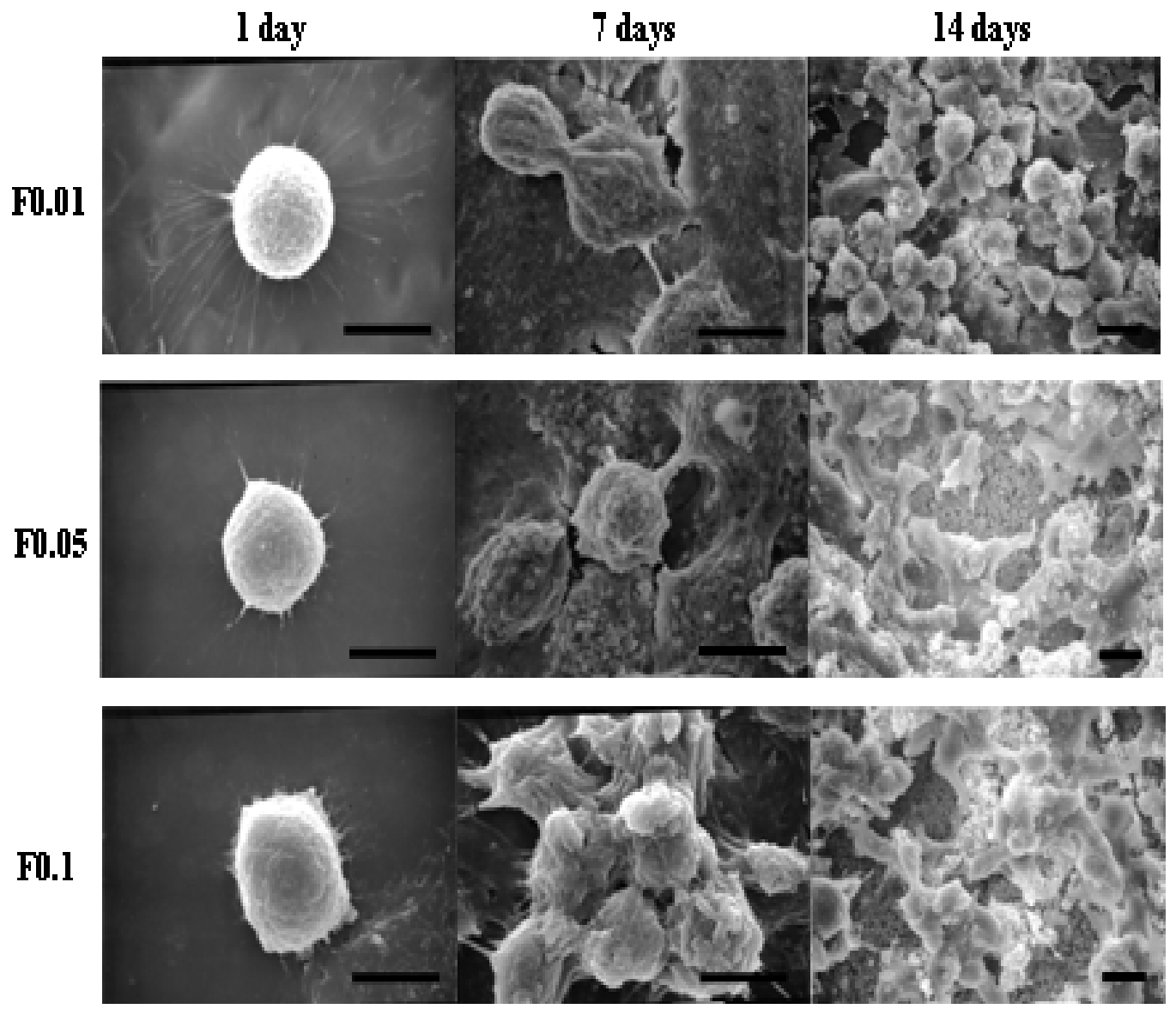

Fig.3 (C). Scanning electron microscopy (SEM) micrographs showing the morphology of odontoblast-like cells (MDPC-23) in culture media containing: (C) F ions $(0.01,0.05,0.1 \mathrm{mM})$ compared to control after 1 day, 7 days, and 14 days. Precipitation on the bottom of the well (arrows) was observed. Bar showed $10 \mathrm{~mm}$.

had a dose dependent effect on mineralization. MDPC23 cells of higher concentration of Sr groups were more deformed compared to control group by TEM observation. This study showed that mineralization was promoted at low $\mathrm{F}$ concentration in a dosedependent manner. However inhibitory effect of $\mathrm{F}$ on proliferation of MDPC-23 cells at higher concentration was observed. According to the results of Von Kossa staining and SEM analysis, cells in media containing high $\mathrm{F}$ concentration produced more nodules than the control group, but the mineralized granules were observed only on the plate and not on the cell surfaces. It is possible that the presence of mineralized granules on the plate may not have been produced by the cells. The cell shape by TEM observation was changed in high F concentration.

Odontoblast-like cells have not been extensively studied compared with osteoblast-like cells. Results from this preliminary study indicated that $\mathrm{Mg}$, Sr, or F ions affect the activities (proliferation and mineralization) of odontoblast-like cells and these effects depend on their concentration levels in the environment.

\section{Acknowledgment}

We thank Tadao Zoda for his technical support. This study was 10 supported by Calcium Phosphate Research Fund, and L. Linkow Professorship in Implant Dentistry, New York University, and Grant-in-Aid for Scientific Research (A) from the Japanese Ministry of Education, Culture, Sports, Science and Technology. (No.15209060)

\section{References}

1. Farley J.R., Wergedal J.E. and Baylink D.J.: Fluoride directly stimulates proliferation and ALP activity of bone-forming cells. Science 222:330,1983

2. Neufeld E.B. and Boskey A.L.: Strontium alters the complexed acidic phospholipid content of mineralized tissue. Bone 15:425-430,1994

3. Wergedal J.E., Lau K.H.W. and Baylink D.J.: Fluoride and bovine bone extract influence cell proliferation and phosphatase activities in human bone cell cultures. Clin 4.

Orthop Rel Res 233:274-282,1988

4. Wiesmann H.P., Tkotz T., Joos U., Zierold K., Stratmann U., Szuwart T., Plate U. and Hohling H.J.: Magnesium in newly formed dentin mineral of rat incisor. J Bone Miner Res 12:380-383,1997 

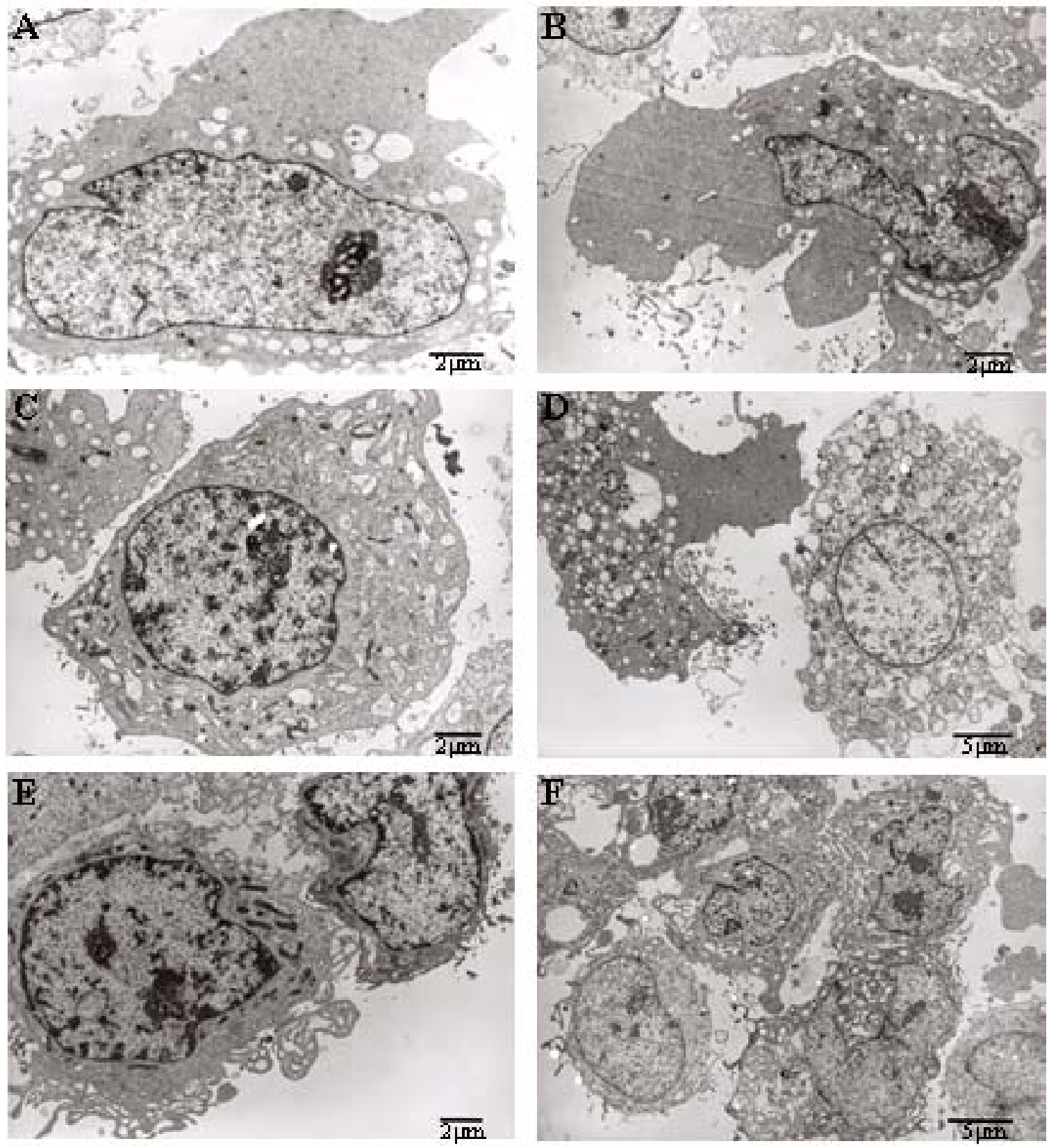

Fig.4 Transmission electron microscopy (TEM) micrographs showing the morphology of MDPC-23 cells in culture media containing: (A,B) control, (C) 1mM Mg ions, (D) 10mM Mg ions, (E) 1mM Sr ions, (F) 0.1mM F ions after 14 days.

5. Antich P.P., Boivin G. and Meunier P.J.: Dependence of bone quality, mineral density and fluoride content on the mode of fluoride administration. J Bone Mineral Res 7:S198,1992

6. Dhert W.J.A., Klein C.P.A.T., Jansen J.A., Van Der Velde E.A., Vriesde R.C., Rozing P.M. and De Groot K.: A histological and histomorphometrical investigation of fluoroapatite, magnesium whitlockite, and hydroxylapatite plasma sprayed coatings in goats. J Biomed Mater Res 27:127-138,1993

7. Grynpas M. and Marie P.J.: Effect of low doses of strontium on bone quality and quantity in rats. Bone 11:313-319,1990

8. Boskey A.L., Rimnac C.M., Bansal M., Federmann M., Lian
J. and Boyan B.D.: Effect of short-term hypomagnesia on the chemical and medical properties of rat bone. J Orthop Res 10:774-783,1992

9. LeGeros R.Z., Daculsi G., Kijkowska R. and Kerebel B.: The effect of magnesium on the formation of apatites and whitlockites. In: Magnesium in Health and Disease, ed. by Itokawa Y and Durlach J, John Libbey and Co., Ltd., New York, 1989, pp11-19. Book

10. Spencer P., Barnes C., Martini J., Garcia R., Elliott C. and Doremus R.: Incorporation of magnesium into rat dental enamel and its influence on crystallization. Arch Oral Biol 34:767-771,1989 
Miho Inoue et.al.: Effect of Mg, Sr, F ions in vitro activities of MDPC23

11. Tsuboi S., Nakagaki H., Ishiguro K., Kondo K., Mukai M., Robinson C. and Weatherell J.A.: Magnesium distribution in human bone. Calcif Tissue Int 50: 34-37,1992

12. Reinholt F.P., Engfeld B., Heinerars D. and Hjerpe A.: Proteoglycans and glycoaminoglycans of normal and strontium rachitic epiphyseal cartilage. Collag Rel Res 5: 4153,1985

13. Storey E.: Calcium and strontium changes in bone associated with continuous administration of stable strontium to rats. Arch Biochem Biophys 103: 575-581,1968

14. Matsumoto A.: Effect of strontium on the epiphyseal cartilage plate of rat tibiae histological and radiographic studies. Jpn J Pharmacol 26: 675-681,1976

15. Wadkins C.L. and Peng C.F.: Strontium metabolism and mechanism of interaction with mineralizad tissues. In: Handbook of stable strontium, ed. by Skoryna SC, New York, 1981, pp 545-561. Book

16. Sobel A.E.: Local factors in the mechanism of calcification. Ann NY Acad Sci 60:713-732,1954

17. Omdahl J.L.: Control of kidney 25-hydroxyvitamin D3 metabolism: Strontium and the involvement of parathyroid hormone. Arch Biochem Biophys 184:172-178,1977

18. Janes J.M. and Mccaslin F.: The effect of strontium lactate in the treatment of osteoporosis. Proc Mayo Clin 34:329334,1959

19. Pak C.Y., Sakhaee K., Zerwekh J.E., Parcel C., Peterson R. and Johnson K.: Safe and effective treatment of osteoporosis with slow-release sodium fluoride; augmentation of vertebral mass and inhibition of fractures. J Clin Endocrin Metab
68:150-159,1989

20. Boivin G., Chavassieux P., Chapuy M.C., Baud C.A. and Meunier P.J.: Skeletal fluorosis: histomorphometric analysis of bone changes and bone fluoride content in 29 patients. Bone 10:89-99,1989

21. Grynpas M.D., Hamilton E., Cheung R., Tsouderos Y., Deloffere P., Hott M. and Marie P.J.: Strontium Increases Vertebral Bone Volume in Rats at a Low Dose That Does Not Induce Detectable Mineralization Defect. Bone 18:253259,1996

22. Frondoza C.G., LeGeros R.Z. and Hungerford D.S.: Effect of bovine bone derived materials on human osterblast-like cells in vitro. Bioceramics 11:289-291,1998

23. Kazimiroff J., Frankel S.R. and LeGeros R.Z.: Bone/ biomaterial interface: Autoradiographic assessment. Bioceramics 9:169-172,1996

24. Winters J., Kleckner A., LeGeros R.Z., Vernillo A. and Rifkin B.: Fluoride inhibits osteoclastic bone resorption in vitro. J Dent Res 68:353,1989

25. Sakae T., Hoshino K., Fujimori Y., Kozawa Y. and LeGeros R.Z.: In vitro interactions of bone marrow cells with carbonate and fluoride containing apatites. Bioceramics 13:347-350,2000

26. Hanks C.T., Fang D., Sun Z., Edwards C.A. and Butler W.T.: Dentin-specific proteins in MDPC-23 cell line. Eur J Oral Sci 106:260-266,1998

27. Serre C.M., Papillard M., Chavassieux P., Voegel J.C. and Boivin G.: Influence of magnesium substitution on a collagenapatite biomaterial on the production of a calcifying matrix by human osteoblasts. J Biomed Mater Res 42:626-633,1998 